\title{
Increasing customer loyalty and customer intimacy by improving the behavior of employees
}

\section{INTRODUCTION}

One of the most important goals of every organization is to serve customers as best as possible (de Waal, 2012). In order to fulfill this goal, employees of the organization need to realize that customers are the most important thing in the world to them, and that without satisfied customers the organization does not have a reason to exist. In practice, this means that employees have to behave in such a way toward customers that these customers are not only fully satisfied with the service provided at a particular moment, but, in a longer-term perspective, become loyal to the organization. In the past decade, researchers have reported that customer loyalty goes beyond customer satisfaction as the latter points at the result of one or a limited number of encounters between customers and organizations, while the former refers to an ongoing relation between these customers and organizations (Bügel, 2010). Customer loyalty has many advantages for an organization: favorable word of mouth marketing, justified price premiums, reduced employee training costs, and lower employee turnover, all resulting in higher firm profits (Yim et al., 2008; Bügel, 2010). A study among twelve USA industries found that organizations that focused on increasing customer loyalty experienced double-digit profits from customers willing to buy more from them, customers being reluctant to switch business away from them, and customers likely to recommend them more often. Concretely, it was found that a modest improvement in customer loyalty could result in between $\$ 179$ million (for health insurance companies) and $\$ 308$ million (for hotel chains) of incremental revenue over three years, for every $\$ 1$ billion in annual sales (Temkin, 2011). As Setó-Pamies (2012, p. 1257) concludes: "Customer loyalty gives companies a competitive advantage that is sustainable over time and is therefore the key to success. Few businesses can survive without establishing a loyal customer base.”

Despite numerous studies into the nature of customer loyalty (Al-Awadi, 2002; Chang et al., 2009; Kuo and Ye, 2009; Yieh et al., 2007; Yu et al., 2005), there appears to be no general accepted definition in the literature of the construct of customer loyalty (Setó-Pamies, 2012). Its conceptualization seems to be based on a collection of factors, such as, among others, trust, where the customer trusts the vendor or product; perceived value of the product or service 
provided, which has to be greater than that supplied by competitors; and emotional attachment, where the customer develops a commitment to the vendor which is resistant to change (Pitta et al., 2006; Reichheld, 1996). Another factor which in recent years is increasingly seen to be of importance in the customer-organization relationship is customer intimacy (Treacy and Wiersma, 1993). Customer intimacy is defined as "making customers feel good whenever they make contact with your company" (Ballou, 2006, p. 5) or, alternatively, "tailoring and shaping products and services to fit the increasingly specific definition of the customer" (Bügel, 2010, p. 65). Previous empirical work has shown that the interaction between the service employee and the customer is the most important determinant of customer intimacy (Fleming et al., 2005; Lloyd and Luk, 2011; Pitta et al., 2006) For instance, Yim et al. (2008) found that exceptional service during the customer-employee interaction drives customer-firm intimacy and customer loyalty, and thus profitability (Lau, 2000; Xu and Van der Heijden, 2005).

In the scholarly literature, many models and accompanying scales for measuring the quality of service can be found; for instance the synthesized model of service quality from Brogowicz et al. (1990), the IT (Information Technology) alignment model from Berkley and Gupta (1994), the service quality and satisfaction model developed by Spreng and Mackoy (1996), the PCP (Pivotal, Core, Peripheral) attribute model from Philip and Hazlett (1997), the retail service quality and perceived value model of Sweeney et al. (1997), the customer value and customer satisfaction model developed by Oh (1999), the antecedents and mediator model of Dabholker et al. (2000), the internal service quality model by Frost and Kumar (2000), the internal service quality DEA (data envelope analysis) model from Soteriou and Stavrinides (2000), the service quality model for internet banking proposed by Broderick and Vachirapornpuk (2002), the service quality model for IT related business developed by Zhu et al. (2002), and the model of e-service quality from Santos (2003). Three of the most widely used models are SERVQUAL (Parasuraman et al., 1988; Vijayvargy, 2014), SERVPERF (Cronin and Taylor, 1994), and the Grönroos model (Grönroos, 1984, 2000). The SERVQUAL (which stands for Service Quality) scale measures service quality as the difference between expectations and perceptions of customers while the SERVPERF (which stands for Service Performance) scale measures the result of the service. In contrast, the scale of Grönroos' Augmented Services Offering (ASO) model takes into account technical quality, functional quality, and company image, as these are seen as justifications for the service quality a firm provides. In the literature there is a debate about which is the better scale, with the controversies centering 
around the alleged one-sided focus on the service delivery process while service quality is a more encompassing construct, or whether a certain scale is too American-based without taking the European context into account, or whether a scale is too complicated (Jeffrey James, 2004; Vijayvargy, 2014). There is however another contention point which might have been missed thus far in this debate. Many researchers regard service quality levels, which is measured by the above-mentioned scales, as antecedents for customer satisfaction, which, in turn, should correlate with overall attitudinal loyalty of customers (Kumar et al., 2010; Rahman et al., 2012). However, these scales do not measure the actual behaviors which employees need to display in order to create and strengthen customer intimacy and customer loyalty, they provide information about the outcome of these behaviors (Dabholkar et al., 2000). In this respect, there seems to be a gap in the literature as there is - to the best of our knowledge- no validated listing of the behaviors which need to be shown by employees to achieve the high service quality, and herewith increased customer intimacy and customer loyalty. To address this gap in the literature, the research question that is central in our study is formulated as follows: What kind of behaviors does an employee need to display during the customer-employee interaction, in order for the customer to experience customer intimacy which in turn creates customer loyalty?

The main objective of this study was to develop a psychometrically sound instrument for the measurement of employee behavior. Thus, in this study we aim to generate validated measures for the behaviors that employees need to display in order to provide excellent service. More specifically, these behaviors should have predictive value in the light of customer loyalty. In order to do so, first, we will go into a thorough search of the scholarly literature to find out which ingredients are important to take into account in our conceptualization of the behavioral factors needed to create customer loyalty. Next, we will deal with the operationalization of the concept into a set of questionnaire items that are thought to be representative for the construct of customer loyalty and its comprising factors. Finally, the psychometric validation of the instrument will be discussed.

This article is structured as follows. First the theory of customer loyalty and behaviors leading to customer loyalty is discussed. Then, the research methodology is described and the research results are given. The article ends with a conclusion, the limitations of the study, and opportunities for future research. The research described in this article will add to the literature in the sense that it goes beyond the much researched topic of customer satisfaction, 
by incorporating the concepts of customer loyalty and customer intimacy which are important in terms of positive outcomes for organizations in the longer run.

\section{BEHAVIORS LEADING TO CUSTOMER LOYALTY}

Aksoy (2013) succinctly describes the mechanism that leads from employee behaviors to customer loyalty. First, the organization has to understand what constitutes customer loyalty, i.e. the organization should clearly define what a loyal customer means so that it can be measured and managed in line with the organization's strategic goals. Then, the organization should actually put practices in place to (a) track customers' loyalty with various performance indicators, such as customer satisfaction and customer complaints; and (b) engage customers with the organization in an effort to increase the results on these performance indicators. Lastly, the organization has to act on the outcomes of the performance indicators in order to influence the attitude of customers positively.

The literature provides a plethora of performance indicators with which to measure and track customer intimacy and customer loyalty. Yim et al. (2008) looked at the ways a fast food restaurant and a hair salon created customer loyalty and customer intimacy through fostering customer-firm affection, which is defined as the affectionate bond that develops over time between a customer and an organization. The authors found that customer-firm affection complements satisfaction and trust in developing customer loyalty. More specifically, their research showed that customer-firm affection can be greatly enhanced by adding excitement to the service delivered, as this excitement entices customer passion. From their validated measurement scale, the items that deal with the behavior of employees - and the effect of this behavior on customers - during the customer-firm interaction were selected for our study. The items that pertain to the product or to the organization (like organizational policies) were not selected as our study focuses on customer satisfaction, customer intimacy, and customer loyalty, created by the satisfaction of customers with the behaviors employees showed. Our study does not deal with satisfaction created by the features of the organization or its products.

Thus, the validated scale of Yim et al. (2008) was taken as the basis for the questionnaire in our research. However, other researchers have found additional factors and items which also seemed of importance to customer intimacy and customer loyalty. We have reviewed these factors and items and added those that were not present in the Yim et al. scale. For instance, 
Dixon et al. (2010) found - in contrast to Yim et al. (2008) - that it was not so much about providing a great service experience and delighting the customers, but rather about getting the basics right and reducing the effort for customers to solve their problem that builds customer loyalty. These authors therefore stated that the emphasis of customer service interactions had to be changed toward solving the problem of the customer quickly and easily. Unfortunately, the authors did not come up with possible measurement items but, based on their description of the five tactics high performance organizations used, we derived items for the four tactics that deal with behavior. The tactics 'Don't just resolve the current issue, head off the next one' and 'Focus on problem solving, not on speed' were translated into two items ('The employee solved my problem quickly' and 'The employee solved my problem completely'), and the tactics "Arm sales representatives to address the emotional side of customer interactions' and 'Listen to and learn from disgruntled customers' were operationalized into one item ('The employee was sympathetic to my situation').

Bügel (2010) investigated the development of customer intimacy in five industries and found that it contributed significantly to creating customer commitment to the organization, and eventually to customer loyalty. Bügel's research showed that investing in intimacy particularly paid off during the beginning and the ending of the relationship, and that customer intimacy could help with building customer relationships, and with preventing these relationships to end. Bügel measured the level of intimacy, passion and commitment that a customer experiences in general with an organization, however he did not go into specific behaviors of the organizational employee. We therefore decided to build upon the validated general organizational items in regard to intimacy as developed by Bügel (2010) and translated these into general individual behavioral items.

Mechinda and Patterson (2011) examined the effects of the personality of the service provider as well as service climate and job satisfaction on customer-oriented behavior in a hospital setting. They found that various personality traits had differing effects on customer-oriented behaviors of front-line employees, i.e. nurses. We adjusted the items that the authors used to measure the behavior of the nurses and generalized these (i.e. from 'patients' to 'customers'). Lloyd and Luk (2011, p. 178) investigated the service behaviors that were supposed to elicit a sense of comfort for the customer during the employee-customer interaction, in which comfort was defined as "an emotion characterized by feeling at ease due to lack of anxiety in a service interaction." The authors found that overall comfort of customers of fashion apparel shops and casual dining restaurants positively impacted both overall quality and customer satisfaction, which ultimately led to positive word-of-mouth. The sense of customer comfort 
appeared to be created by two key groups of interaction behavior that contained specific behaviors: the effort employees made to understand customers, and their courteous behavior toward customers.

Creating an organizational climate that is aimed at providing excellent service was found to be important to guarantee that customers receive high-quality service (Bowen and Schneider 1988). The satisfaction of employees with this organizational service climate was referred to as an employee perception of internal customer satisfaction (Xu and Van der Heijden, 2005). Jun and Cai (2010), while researching the dimensions of internal customer satisfaction, found that customer intimacy was the most influential dimension to achieve both high internal customer service quality, and subsequently, satisfaction. As internal customer satisfaction leads to external customer satisfaction, we made the assumption - just as Garvin (1988) did that the behavior displayed by employees to achieve internal customer intimacy might be the same as the ones needed for achieving external customer intimacy. We therefore incorporated the items found by Jun and Cai (2010) for customer intimacy as well.

Winsted (2000) examined the behaviors of service providers that influenced the customer evaluation of the service encountered during restaurant and medical transactions and, subsequently, tied these behaviors to customer satisfaction. Although, as stated before, we were looking for behaviors that influence customer loyalty and customer intimacy, achieving customer satisfaction was one of the core components of achieving customer loyalty, and therefore we decided to include the behaviors as found by Winsted (2000) as well.

Sirdeshmukh et al. (2002) looked into both the behaviors and practices of service providers that built or depleted consumer trust, and into the mechanisms that converted consumer trust into loyalty to the organization. Their framework used a multi-dimensional conceptualization for trustworthiness, and incorporated two distinct facets of consumer trust: frontline employees and management policies. The scholars tested their framework among respondents from retail clothing stores and non-business airline travel agencies. We selected the validated items that Sirdeshmukh et al. (2000) developed for the behaviors of frontline employees.

Finally, Dabholkar et al. (2000) investigated the factors that predict service quality among the customers of a photographic company that made pictorial membership directories for churches, and found several behaviors from employees that appear to lead to higher service quality. We selected these as well for inclusion in our study.

\section{THE RESULTING ITEM LIST}


As stated before, the scale by Yim et al. (2008) formed the basis of the list of measurement items to be used in this research, and it was supplemented with factors and corresponding items from other researchers. The items were grouped by aggregating similar items under one factor with an appropriate description. The items were (re)worded in such a way that each item started with 'The employee ...' so it would be clear in the questionnaire that we were looking for the behavior of employees. Items have been formulated by the first author and cross-validated in an expert meeting consisting of a multidisciplinary group of scholars (covering the fields of behavioral science and marketing) including the second author. For all behavioral factors and corresponding items the literature sources from which the items were derived are given in Appendix 1. Looking at the items in Appendix 1, it can be said that we define customer intimacy as Ballou (2006) but with an adaptation: 'customer intimacy is the good feeling that is created with employees by the behavior of the organization's employees.'

As stated before, in order to test whether the factors had predictive validity, i.e. whether they showed a significant relationship with customer loyalty, the scale of Yim et al. (2008) for loyalty intentions was used as the dependent. We added the scale for commitment of Bügel (2010) to Yim et al.'s scale, as the former comprised some items specifically dealing with the degree of loyalty the customer feels toward an organization. Finally, we added one item of Sirdeshmukh et al. (2002) which measured the loyalty of a customer toward an organization. Appendix 2 shows the specific scale items and literature sources. Looking at the items in Appendix 2, it can be noticed that we basically concur with the definition of Oliver (1999, p. 34) of customer loyalty: 'A deeply held commitment to rebuy or repatronize a preferred product/service consistently in the future, thereby causing repetitive same-brand or same brand-set purchasing, despite situational influences and marketing efforts having the potential to cause switching behavior.' The items in Appendix 2 show that for customer loyalty not only customers need to have an affective bond to the organization's product/service but also need to act accordingly, i.e. staying loyal to the organization even when enticed to not do so.

\section{RESEARCH METHODOLOGY}

The items for the behavioral factors that are assumed to predict customer intimacy and customer loyalty were collected in one survey. We did not make a distinction between transactional interactions (such as those taking place in a fast food restaurant) and relational interactions (such as the ones in a hair salon) because Yim et al. (2008) found in practice no 
great differences between these two types of interactions. The questionnaire was distributed to the personnel of a client of one of the authors, a large company in the media sector in the Netherlands which catered to both business and individual customers and which preferred to remain anonymous. As such, we used a convenience sample: this organization was interested in the topic of customer intimacy and customer loyalty and therefore made its employees available for participating in our research. This research therefore did not constitute a case study of a particular company, we were interested in the opinions of employees as customers of other organizations. No selection of participants was made as the possible respondents were asked to participate on the basis of their availability, and because no selection needed to be made as all potential respondents were in daily life on a regular basis customers of other companies. The respondents were asked to reply on the following question: "Please think back to a time when you encountered first-rate service which surpassed your expectations, and rate on a scale of 1 (not important at all) to 10 (very important) the importance of the following behaviors during that encounter of the company's service employee for your outstanding experience ..." In addition, the respondents were asked to indicate how likely it was that they would choose the organization again when requiring new service (see Appendix 3 for the full questionnaire). The survey yielded 117 responses. After removing the questionnaires which were not completed fully, 110 valid responses remained.

In our approach, both the reliability and validity of the measurement instrument were optimized by means of using (statistical) validation techniques. More specifically, the multidimensional survey consisted of eight dimensions, which can be considered as a set of eight instruments (de Groot, 1961) (see the previous section to understand the basis for the item pools). First, a face validity analysis, that is, a renewed content analysis of the existing dimensions (scales) of the instrument in an expert group of scientists (see also Kidder and Judd, 1986) was performed, followed by a reliability analysis (using Cronbach's alpha), and factor-analytic techniques. Moreover, a thorough linguistic evaluation of the different items was also taken into account. Different methods of test construction (Oosterveld and Vorst, 1996) were used to further optimize the psychometric qualities of the instrument. Concretely, the validity was thoroughly investigated by studying the correlation structure of all items in the eight measurement scales. In order to support the idea of multi-dimensionality, the items within one scale should correlate substantially with one another. The items from separate dimensions should correlate to a certain extent since they form part of one concept, namely high performance behavior aimed at increasing customer loyalty. On the other hand, the 
correlations between items from separate dimensions should not be too high. Badly differentiating items (items that did not discriminate sufficiently) and non-scale fitting items for the distinguished behavioral factors (see Appendices 1 and 2) were therefore eliminated. After the elimination of these items the reliability of the eight scales was investigated. Further homogeneity of the eight separate dimensions was established by using CFA (Confirmatory Factor Analysis). Subsequently, the correlations between the high performance behavior scales and the customer loyalty items were studied. The latter research step refers to the socalled criterion validity.

\section{RESULTS}

We have eliminated cross-loadings that were above .40 . Thus, six items $(16,17,26,27,60$, and 61) were removed as they cross-loaded on more than one factor, herewith violating the requirements for discriminant validity. As a result, of the total original set of 62 items 56 items remained. The structure of the eight dimensions of the employee behaviors are not fully mutually exclusive, however, they appeared to represent correlated aspects. Therefore, after appropriate analyses, the representation (or the factor structure) of the construct as whole, i.e. employee behaviors, was oblique instead of orthogonal. However, after having eliminated six items that showed rather high cross-loadings, the distinctive power of the different dimensions was satisfying, showing sound discriminant validity. Table 1 shows the outcomes of the reliability analyses, using Cronbach's alpha, and all separate item loadings. The results showed good reliabilities for each behavioral factor and item loadings appeared to be all $\geq .4$, herewith supporting both convergent and divergent item validity.

\begin{tabular}{|c|c|c|c|}
\hline Behavioral factor & Cronbach $\alpha$ & Behavioral item & Loading \\
\hline \multirow[t]{6}{*}{ 1. Service quality } & .90 & $\begin{array}{l}\text { 1. The employee provided prompt } \\
\text { services }\end{array}$ & .660 \\
\hline & & $\begin{array}{l}\text { 2. The employee provided accurate } \\
\text { services }\end{array}$ & .820 \\
\hline & & $\begin{array}{l}\text { 3. The employee provided reliable } \\
\text { service }\end{array}$ & .784 \\
\hline & & $\begin{array}{l}\text { 4. The employee solved your problem } \\
\text { quickly }\end{array}$ & .774 \\
\hline & & $\begin{array}{l}\text { 5. The employee solved your problem } \\
\text { completely }\end{array}$ & .795 \\
\hline & & 6. The employee provided complete & .795 \\
\hline
\end{tabular}




\begin{tabular}{|c|c|c|c|}
\hline & & service & \\
\hline & & $\begin{array}{l}\text { 7. The employee went out of their way } \\
\text { to solve your problems }\end{array}$ & .694 \\
\hline & & $\begin{array}{l}\text { 8. The employee performed the service } \\
\text { right the first time }\end{array}$ & .769 \\
\hline & & $\begin{array}{l}\text { 9. The employee's service had much } \\
\text { added value for you }\end{array}$ & .682 \\
\hline \multirow[t]{6}{*}{ 2. Empathy } & .89 & $\begin{array}{l}\text { 10. The employee was very } \\
\text { understanding of your situation }\end{array}$ & .786 \\
\hline & & $\begin{array}{l}\text { 11. The employee gave you personal } \\
\text { attention }\end{array}$ & .885 \\
\hline & & 12. The employee cared about you & .884 \\
\hline & & $\begin{array}{l}\text { 13. The employee asked you how you } \\
\text { were }\end{array}$ & .674 \\
\hline & & 14. The employee treated you carefully & .756 \\
\hline & & 15. The employee was warm & .819 \\
\hline \multirow[t]{8}{*}{ 3. Trust } & .91 & $\begin{array}{l}\text { 18. The employee's opinion was honest } \\
\text { and reliable }\end{array}$ & .661 \\
\hline & & $\begin{array}{l}\text { 19. The employee was a person you } \\
\text { could trust }\end{array}$ & .863 \\
\hline & & $\begin{array}{l}\text { 20. The employee was a person you had } \\
\text { a confidential relationship with }\end{array}$ & .638 \\
\hline & & $\begin{array}{l}\text { 21. The employee's behavior instilled } \\
\text { confidence in you }\end{array}$ & .848 \\
\hline & & $\begin{array}{l}\text { 22. The employee made you feel safe in } \\
\text { your transaction with the } \\
\text { organization }\end{array}$ & .895 \\
\hline & & 23. The employee was sincere & .822 \\
\hline & & $\begin{array}{l}\text { 24. The employee made you feel } \\
\text { comfortable }\end{array}$ & .867 \\
\hline & & $\begin{array}{l}\text { 25. The employee was natural and } \\
\text { genuine }\end{array}$ & .756 \\
\hline \multirow[t]{6}{*}{$\begin{array}{ll}\text { 4. } & \text { Needs } \\
\text { understanding }\end{array}$} & .92 & $\begin{array}{l}\text { 28. The employee tried to meet your } \\
\text { needs }\end{array}$ & .884 \\
\hline & & $\begin{array}{l}\text { 29. The employee considered what you } \\
\text { had to say }\end{array}$ & .839 \\
\hline & & $\begin{array}{l}\text { 30. The employee was interested in your } \\
\text { needs }\end{array}$ & .883 \\
\hline & & 31. The employee anticipated your needs & .893 \\
\hline & & $\begin{array}{l}\text { 32. The employee asked for your } \\
\text { preferences }\end{array}$ & .736 \\
\hline & & 33. The employee understood your needs & .866 \\
\hline
\end{tabular}




\begin{tabular}{|c|c|c|c|}
\hline & & $\begin{array}{l}\text { 34. The employee treated you as a valued } \\
\text { customer }\end{array}$ & .666 \\
\hline \multirow[t]{8}{*}{ 5. Courtesy } & .92 & $\begin{array}{l}\text { 35. The employee was courteous with } \\
\text { you }\end{array}$ & .758 \\
\hline & & 36. The employee respected you & .717 \\
\hline & & 37. The employee was helpful & .843 \\
\hline & & 38. The employee was attentive & .817 \\
\hline & & $\begin{array}{l}\text { 39. The employee showed patience with } \\
\text { you }\end{array}$ & .796 \\
\hline & & $\begin{array}{l}\text { 40. The employee addressed complaints } \\
\text { in a friendly manner }\end{array}$ & .852 \\
\hline & & 41. The employee was polite & .864 \\
\hline & & $\begin{array}{l}\text { 42. The employee was not annoyed with } \\
\text { you }\end{array}$ & .795 \\
\hline \multirow[t]{5}{*}{ 6. Responsiveness } & .88 & $\begin{array}{l}\text { 43. The employee was responsive to your } \\
\text { questions and requests }\end{array}$ & .859 \\
\hline & & $\begin{array}{l}\text { 44. The employee took the time to give } \\
\text { you service }\end{array}$ & .795 \\
\hline & & $\begin{array}{l}\text { 45. The employee was readily available } \\
\text { when you needed him }\end{array}$ & .758 \\
\hline & & $\begin{array}{l}\text { 46. The employee gave you his full } \\
\text { attention }\end{array}$ & .903 \\
\hline & & $\begin{array}{l}\text { 47. The employee was fully engaged } \\
\text { with you }\end{array}$ & .828 \\
\hline \multirow[t]{6}{*}{ 7. Capability } & .89 & 48. The employee was intelligent & .839 \\
\hline & & 49. The employee was capable & .861 \\
\hline & & $\begin{array}{l}\text { 50. The employee behaved in a } \\
\text { professional manner }\end{array}$ & .840 \\
\hline & & $\begin{array}{l}\text { 51. The employee showed passion for } \\
\text { their job }\end{array}$ & .709 \\
\hline & & 52. The employee was knowledgeable & .836 \\
\hline & & $\begin{array}{l}\text { 53. The employee knew what they were } \\
\text { doing }\end{array}$ & .775 \\
\hline \multirow[t]{6}{*}{ 8. Service manner } & .92 & $\begin{array}{l}\text { 54. The employee was happy and } \\
\text { cheerful }\end{array}$ & .816 \\
\hline & & 55. The employee smiled a lot & .860 \\
\hline & & $\begin{array}{l}\text { 56. The employee had a sincere facial } \\
\text { expression }\end{array}$ & .868 \\
\hline & & 57. The employee was enthusiastic & .832 \\
\hline & & 58. The employee talked with you & .752 \\
\hline & & 59. The employee did not act arrogantly & .879 \\
\hline
\end{tabular}


Table 1: Overview of the behavioral factors of influence on creating customer intimacy, their reliabilities, and all item loadings

The association between the eight behavioral factors in Table 1 and the customer loyalty items in Appendix 2 was investigated in order to determine which factors were significantly related with customer loyalty. The results, given in Table 2, showed that for all behavioral factors the relationship with customer loyalty was significant. This implied that employees that displayed behavior that was in line with the eight behavioral factors were likely to create a positive customer experience, and thereby positively contributed to increasing customer loyalty and strengthening customer intimacy. Overall, these correlations provide preliminary evidence for the predictive validity of the behavioral factors in the light of customer loyalty, given its positive association with all outcome measures. An exception lies in the association with the outcome to consider switching to another company. Obviously, in line with our expectation, this relationship is negative. Future research, using longitudinal designs, is needed to address issues of causality. Given the exploratory character of our contribution, and as the development of a new measurement instrument was the focus of our attention, we have decided to base ourselves upon a thorough analyses of correlational patterns only.

\begin{tabular}{|c|c|c|c|c|c|c|c|}
\hline $\begin{array}{l}\text { Behavioral } \\
\text { factor }\end{array}$ & $\begin{array}{l}\text { First } \\
\text { choice }\end{array}$ & $\begin{array}{l}\text { Prefe- } \\
\text { rence }\end{array}$ & Visits & Loyalty & $\begin{array}{c}\text { Commit } \\
\text {-ment }\end{array}$ & Switch & $\begin{array}{c}\text { Recommen } \\
\text {-dation }\end{array}$ \\
\hline $\begin{array}{l}\text { 1. Service } \\
\text { quality }\end{array}$ & $.67 * *$ & $.69 * *$ & $.65 * *$ & $.56^{* *}$ & $.49^{* *}$ & $-.34 * *$ & $.64 * *$ \\
\hline 2. Empathy & $.48 * *$ & $.44 * *$ & $.40 * *$ & $.39 * *$ & $.32 * *$ & $-.17 * *$ & $.45^{* *}$ \\
\hline 3. Trust & $.66^{* *}$ & $.65^{* *}$ & $.61 * *$ & $.54 * *$ & $.41^{* *}$ & $-.25 * *$ & $.61 * *$ \\
\hline $\begin{array}{l}\text { 4. Needs } \\
\text { understanding }\end{array}$ & $.63 * *$ & $.65 * *$ & $.60 * *$ & $.57 * *$ & $.40^{* *}$ & $-.30 * *$ & $.57 * *$ \\
\hline 5. Courtesy & $.61 * *$ & $.60^{* *}$ & $.54 * *$ & $.53 * *$ & $.38 * *$ & $-.29 * *$ & $.54 * *$ \\
\hline $\begin{array}{l}\text { 6. Respon- } \\
\text { siveness }\end{array}$ & $.61 * *$ & $.61 * *$ & $.58 * *$ & $.55^{* *}$ & $.35^{* *}$ & $-.35 * *$ & $.56 * *$ \\
\hline 7. Capability & $.65 * *$ & $.63 * *$ & $.59 * *$ & $.62 * *$ & $.45^{* *}$ & $-.32 * *$ & $.56^{* *}$ \\
\hline 8. Service & $.58 * *$ & $.54 * *$ & $.49 * *$ & $.40^{* *}$ & $.38 * *$ & $-.16^{* *}$ & $.56^{* *}$ \\
\hline
\end{tabular}


$(* *=$ significant at the .01 confidence level)

Table 2: The correlations between the behavioral factors and customer loyalty

When looking at the strengths of the correlations, it is possible to make a ranking of the behavioral factors, from highest to lowest impact on customer loyalty: 1. service quality; 2. capability; 3. empathy; 4. needs understanding; 5. responsiveness; 6. courtesy; 7. service manner; and 8. trust. This order means that the employee first and foremost has to provide high quality service, where high quality service is defined as prompt, quick, accurate, reliable, and complete service, and that is performed right the first time with great added value for the customer. For this to happen, the organization has to make sure it has high quality i.e. capable employees: intelligent, knowledgeable, professional people, with passion for their job. It is also important that customers feel that they are understood by employees who should be understanding, caring, interested, and warm personalities that want to give the customer personal and careful attention. The capabilities and personalities of employees should then show that they are interested in, listen to, think about, and are understanding about what the customers ask, and that they try to meet and even anticipate on their demands, so that the receiving party feels like valued and trusted customers who are treated with courtesy.

\section{CONCLUSION, LIMITATIONS AND FUTURE RESEARCH}

This study yielded the behaviors needed from employees to provide service that surpasses customer's expectations. Now that the most important behaviors are known, an organization has to make sure that its employees are focusing on displaying these behaviors consistently over time, in order to make sure customers will experience the organization as a high performance organization. It is therefore paramount that these high-impact encounters between employees and customers are not mere incidents, the organization needs to achieve a situation where all employees are able to create these encounters across time. In other words, employees are expected to display high performance behavior which result in a constant stream of high-impact encounters, and therefore highly satisfied customers. This is significant because, as Fleming et al. (2005) found, customer satisfaction scores are just averages which might hide the fact that some customers are extremely satisfied while other are dissatisfied, yielding an average of a rather mean customer satisfaction. As Fleming et al. (2005, p. 110- 
111) described it quite vividly: "We have all seen the claims: A major airline touts itself as an industry leader in on-time performance and has the flight departure and arrival data to prove it. A cellular provider claims to be a leader in customer satisfaction, citing an independent study of customers. A retailer announces that it has won an award for being one of the country's best places to work for the fifth year in a row. Each of these summary claims - based on the results of surveys - may be legitimate, but quick reviews of the on-time performance of specific flights, or candid conversations with cellular customers, or visits to several stores in the retail chain, inevitably reveal a considerable range of performance hidden behind the averages. Some flights are never on time; some always are. Some customers experience nothing but problems; others are routinely delighted. And some stores are exceptional places to work, while others are awful. High-level averages of company performance may provide good marketing copy, and they may make executives feel better about their position in the marketplace. But because they obscure the considerable variation from location to location within a company, they don't give managers and executives the information they need to improve performance." An organization therefore has to make sure that the employee behavior that creates and supports customer intimacy is ingrained in every person that has contact with a customer. Therefore, an important practical implication of our study is that, now that the behavioral factors are known, an organization makes sure that its employees are focusing on displaying positive behaviors toward customers consistently over time. Herewith, the latter party will experience the organization as a high-performance organization and will be inclined to developed long-term relationships with it. At the same time, organizations will be enabled to add more value in their encounters with customers, raising the overall satisfaction level with these organizations.

There are several limitations to our study. First, all respondents came from one organization only. Despite the fact that we stressed to these respondents that the questionnaire had to be filled in based on their experience with another company, it cannot be ruled out that the experiences they had with customers while in function at their own company might have influenced their scoring. Second, this one organization was based in the Netherlands so the results cannot be generalized to other companies in the Netherlands or to companies in other countries without further study. The latter will give the opportunity to compare the importance of the distinguished behavioral factors in different cultures. Future research is also needed to cross-validate our outcomes across occupational settings and industry sectors. Third, we had a relatively small sample size which means that the promising psychometric 
qualities of the new measurement instrument we have developed ought to be cross-validated in future research. In a follow-up study, data from more respondents across different professional fields and from different countries across the globe could be collected in order to perform a confirmatory factor analysis using SEM (structural equation modelling). The next step could be to use a moderated SEM model in order to further test the predictive validity of a model wherein the employee behaviors are used as possible predictors for customer loyalty, and to investigate whether this relationship might be moderated by some important factors as well. This might enable us to search for profession- and/or country-specific recommendations for increasing customer loyalty. Fourth, although we have used items which have been validated in previous research, more research is needed to more safely conclude whether we included all items of importance for creating customer intimacy and customer loyalty. Fifth, all data were collected at a single point in time: that is to say, our study was cross-sectional. This implies that further research is needed in order to address the issue of causality and to better understand how these behaviors contribute to the enhancement of customer loyalty. Research using multi-wave designs can provide more specific information about long-term development of customer loyalty (see also Schalk et al., 2011), including detailed information about stability and changes in the variables, and about cross-lagged relationships (de Lange et al., 2003; Taris and Kompier, 2003). Despite these limitations, it can be stated that this research has been successful in identifying behavioral factors that influence the loyalty of customers to an organization positively. Thus, organizations can now aim at improving and strengthening specifically these behavioral factors in their employees, in order to make sure that the organization's customers are serviced as best as possible, herewith enticing them to return to the organization time after time. 


\section{References}

Aksoy, L. (2013), How do you measure what you can't define?, Journal of Service Management, Vol.24 Issue 4, pp. 356-381.

Al-Awadi, A. (2002), A proposed model of customer loyalty in retailing sector based on the Kuwaiti experience, Total Quality Management and Business Excellence, Vol. 13 No. 7, pp. 1035-1046.

Ballou, S. (2006), in: IBM Global Services (2006), CRM: The Myth vs. the New Agenda, executive brief, (accessed June 1, 2011), available at http://www1.ibm.com/services/us/index.wss/multipage/imc/executivebrief/a1008913/1?cntxt=a1005 261.

Berkley, B. J. and Gupta, A. (1994), Improving service quality with information technology, International Journal of Information Management, Vol. 14, pp. 109-121.

Bowen, D. E. and Schneider, B. (1988), Services marketing and management: implications for organizational behavior, In: B. M. Staw and L. L. Cummings (eds.), Research in organizational behavior, Volume 10 (pp. 43-80), Greenwich, CT: JAI Press.

Broderick, A.J. and Vachirapornpuk, S. (2002), Service quality in internet banking: the importance of customer role, Marketing Intelligence \& Planning, Vol. 20 No. 6, pp. 327335.

Brogowicz, A. A., Delene, L. M. and Lyth, D. M. (1990), A synthesised service quality model with managerial implications, International Journal of Service Industry Management, Vol. 1 No. 1, pp. 27-44.

Bügel, M.S. (2010), The application of psychological theories for an improved understanding of customer relationships, PhD-thesis, Rijksuniversiteit Groningen, The Netherlands

Chang, H.H., Wang, Y. and Yank, W. (2009), The impact of e-service quality, customer satisfaction and loyalty on e-marketing: moderating effect of perceived value, Total Quality Management and Business Excellence, Vol. 20 No. 4, pp. 423-443.

Cronin, J.J. and Taylor, S.A. (1994), SERVPREF versus SERVQUAL: reconciling performance based and perceptions-minus-expectations measurement of service quality, Journal of Marketing, Vol. 58, pp. 125-131.

Dabholkar, P.A. (1996), Consumer evaluations of new technology-based self-service operations: an investigation of alternative models, International Journal of Research in Marketing, Vol. 13 No. 1, pp. 29-51. 
Dabholkar, P.A., Shepherd, C.D. and Thorpe, D.I. (2000), A comprehensive framework for service quality: an investigation of critical conceptual and measurement issues through a longitudinal study, Journal of Retailing, Vol. 76 No. 2, pp. 139-173.

de Groot, A.D. (1961), Methodologie. Grondslagen van onderzoek en denken in de gedragswetenschappen. [Methodology. Foundations of research and thinking in the behavioral sciences], Den Haag: Uitgeverij Mouton.

de Lange, A. H., Taris, T. W., Kompier, M. A. J., Houtman, I. L. D. and Bongers, P. M. (2003), The very best of the millennium: longitudinal research and the demand-control(support) model, Journal of Occupational Health Psychology, Vol. 8 No. 4, pp.282-305.

de Waal, A.A. (2012), What makes a high performance organization, five validated factors of competitive performance that apply worldwide, Global Professional Publishing, Enfield.

Dixon, M., Freeman, K. and Toman, N. (2010), Stop trying to delight your customers, Harvard Business Review, July-August: 116-122.

Fleming, J.H., Coffman, C. and Harter, J.K. (2005), Manage your human Sigma, Harvard Business Review, July-August: 107-114.

Frost, F. A. and Kumar, M. (2000), INTSERVQUAL: an internal adaptation of the GAP model in a large service organization, Journal of Services Marketing, Vol. 14 No. 5, pp. 358-377.

Garvin, D. A. (1988), Managing quality, New York: The Free Press.

Grönroos, C. (1984), A service quality model and its implications, European Journal of Marketing, Vol. 18 No. 4, pp. 36-44.

Grönroos, C. (2000), Service Management and Marketing - A Customer Relationship Management Approach, Wiley, Chichester.

Jeffrey James, G.D. K. (2004), Service quality dimensions: an examination of Grönroos's service quality model, Managing Service Quality: An International Journal, Vol. 14 No. 4, pp. $266-277$.

Jun, M. and Cai, S. (2010), Examining the relationships between internal service quality and its dimensions, and internal customer satisfaction, Total Quality Management, Vol. 21 No. 2, pp. 205-223.

Kidder, L.H. and Judd, C.M. (1986), Research methods in social relations, Japan Ltd: CBS Publishing.

Kumar, S.A., Mani, B.T., Mahalingam, S. and Vanjikovan, M. (2010), Influence of service quality on attitudinal loyalty in private retail banking: an empirical study, $S R M$ Management Digest, Vol. 8, pp. 195-213. 
Kuo, Y.K. and Ye, K.D. (2009), The causal relationship between service quality, corporate image and adults' learning satisfaction and loyalty: a study of professional training programmes in a Taiwanese vocational institute, Total Quality Management and Business Excellence, Vol. 20 No. 7, pp. 749-762.

Lau, R. S. M. (2000), Quality of work life and performance: An ad hoc investigation of two key elements in the service profit chain model, International Journal of Service Industry Management, Vol. 11 No. 5, pp. 422-437.

Lloyd, A.E. and Luk, S.T.K. (2011), Interaction behaviors leading to comfort in the service encounter, Journal of Service Marketing, Vol. 25 Issue 3, pp. 176-189.

Mechinda, P. and Patterson, P.G. (2011), The impact of service climate and service provider personality on employees' customer-oriented behavior in a high-contact setting, Journal of Services Marketing, Vol. 25 Issue 2, pp. 101-113.

Oh, H. (1999), Service quality, customer satisfaction and customer value: a holistic perspective, International Journal of Hospitality Management, Vol. 18, pp. 67-82.

Oliver, R.L. (1999), Whence consumer loyalty?, Journal of Marketing, Vol. 63 Issue 4, pp. $33-44$.

Oosterveld, P. and Vorst, H.C.M. (1996), Note on reliability and validity of self-evaluation of ability scales, Perceptual and Motor Skills, Vol. 82, pp. 817-818

Parasuraman, A., Zeithaml, V.A. and Berry, L.L. (1988), SERVQUAL: a multiple -item scale for measuring consumer perceptions of service quality, Journal of Retailing, Vol. 64, pp. $12-40$.

Philip, G. and Hazlett, S. A. (1997), The measurement of service quality: a new P-C-P attributes model, International Journal of Quality \& Reliability Management, Vol. 14 No. 3, pp. 260-286.

Pitta, D., Franzak, F. and Fowler, D. (2006), A strategic approach to building online customer loyalty: integrating customer profitability tiers, Journal of Consumer Marketing, Vol. 23 Issue 7, pp. 421-429.

Rahman, M.S., Khan, A.H. and Haque, Md.M. (2012), A conceptual study on the relationship between service quality towards customer satisfaction: Servqual and Gronroos's service quality model perspective, Asian Social Science, Vol. 8 No. 13, pp. 201-210.

Reichheld, F.F. (1996). The loyalty effect, Harvard Business School Press, Boston.

Santos, J. (2003), E-service quality: a model of virtual service quality dimensions, Managing Service Quality, Vol. 13 No. 3, pp. 233-246. 
Schalk, R., Van der Heijden, B., De Lange, A. and Van Veldhoven, M. (2011), Long-term developments in individual work behaviour: patterns of stability and change, Journal of Occupational and Organizational Psychology, Vol. 84, pp. 215-227.

Setó-Pamies, D. (2012), Customer loyalty to service providers: examining the role of service quality, customer satisfaction and trust, Total Quality Management, Vol. 23 No. 11, pp. 1257-1271.

Sirdeshmukh, D., Singh, J. and Sabol, B. (2002), Consumer trust, value, and loyalty in relational exchanges, Journal of Marketing, Vol. 66, pp. 15-37.

Soteriou, A. C. and Stavrinides, Y. (2000), An internal customer service quality data envelope analysis model for bank branches, International Journal of Bank Marketing, Vol. 18 No. 5, pp. 246-252.

Spreng, R. A. and Mackoy, R. D. (1996), An empirical examination of a model of perceived service quality and satisfaction, Journal of Retailing, Vol. 72 Issue 2, pp. 201-214.

Sweeney, J. C., Soutar, G. N. and Johnson, L. W. (1997), Retail service quality and perceived value, Journal of Consumer Services, Vol. 4 No. 1, pp. 39-48.

Taris, T. and Kompier, M. (2003), Challenges in longitudinal designs in occupational health psychology, Scandinavian Journal of Work, Environment and Health, Vol. 29 No. 1, pp. $1-4$.

Temkin, B. (2011), The customer experience - loyalty connection, Research report, Temkin Group, May 2011.

Treacy, M. and Wiersma, F. (1993), Customer intimacy and other value disciplines, Harvard Business Review, Vol. 77 Issue 1, pp. 84-93.

Vijayvargy, L. (2014), Measuring service quality using SERVQUAL: a case of restaurant chain, International Journal of Management and Innovation, Vol.6 Issue 2, pp. 60 - 72.

Winsted, K.F. (2000), Service behaviors that lead to satisfied customers, European Journal of Marketing, Vol. 34 No. 3/4, pp. 399-417.

Xu, Y. and Van der Heijden, B. (2005), The employee factor in the service-profit chain framework: a study among service employees working within a leading Chinese securities firm, Journal of International Consumer Marketing, Vol. 18 No.1/2, pp. 137155.

Yieh, K., Chiau, Y. and Chiu, Y. (2007), Understanding the antecedents to customer loyalty by applying structural equation modelling, Total Quality Management and Business Excellence, Vol. 18 No. 3, pp. 267-284. 
Yim, C.K., Tse, D.K. and Chan, K.W. (2008), Strengthening customer loyalty through intimacy and passion: roles of customer-firm affection and customer-staff relationships in services, Journal of Marketing Research, Vol. XLV, pp. 741-756.

Yu, C.J., Wu, L., Chiao, Y. and Tai, H. (2005), Perceived quality, customer satisfaction, and customer loyalty: the case of Lexus in Taiwan, Total Quality Management and Business Excellence, Vol. 16 No. 6, pp. 707-719.

Zhu, F.X., Wymer Jr., W. and Chen, I. (2002), IT-bases services and service quality in consumer banking, International Journal of Service Industry Management, Vol. 13 Issue 1, pp. 69-90. 


\section{APPENDIX 1: OVERVIEW OF BEHAVIORAL FACTORS}

This Appendix gives an overview of the behavioral factors and items potentially of influence on creating customer intimacy and customer loyalty.

\begin{tabular}{|c|c|c|}
\hline Behavioral factor & Behavioral item & Sources \\
\hline \multirow[t]{9}{*}{ 1. Service quality } & $\begin{array}{l}\text { 1. The employee provided } \\
\text { prompt services }\end{array}$ & $\begin{array}{l}\text { Yim et al. (2008), Sirdeshmukh et } \\
\text { al. (2002) }\end{array}$ \\
\hline & $\begin{array}{l}\text { 2. The employee provided } \\
\text { accurate services }\end{array}$ & Yim et al. (2008) \\
\hline & $\begin{array}{l}\text { 3. The employee provided } \\
\text { reliable service }\end{array}$ & Yim et al. (2008) \\
\hline & $\begin{array}{l}\text { 4. The employee solved your } \\
\text { problem quickly }\end{array}$ & Dixon et al. (2010) \\
\hline & $\begin{array}{l}\text { 5. The employee solved your } \\
\text { problem completely }\end{array}$ & $\begin{array}{l}\text { Dixon et al. (2010), Sirdeshmukh } \\
\text { et al. (2002) }\end{array}$ \\
\hline & $\begin{array}{l}\text { 6. The employee provided } \\
\text { complete service }\end{array}$ & Winsted (2000) \\
\hline & $\begin{array}{l}\text { 7. The employee went out of } \\
\text { his/her way to solve your } \\
\text { problems }\end{array}$ & Sirdeshmukh et al. (2002) \\
\hline & $\begin{array}{l}\text { 8. The employee performed the } \\
\text { service right the first time }\end{array}$ & Dabholkar et al. (2000) \\
\hline & $\begin{array}{l}\text { 9. The employee's service had } \\
\text { much added value for you }\end{array}$ & Bügel (2010) \\
\hline \multirow[t]{7}{*}{ 2. Empathy } & $\begin{array}{l}\text { 10. The employee was very } \\
\text { understanding of your } \\
\text { situation }\end{array}$ & $\begin{array}{l}\text { Bügel (2010), Mechinda and } \\
\text { Patterson (2011), Winsted (2000), } \\
\text { Dixon et al. (2010) }\end{array}$ \\
\hline & $\begin{array}{l}\text { 11. The employee gave you } \\
\text { personal attention }\end{array}$ & $\begin{array}{l}\text { Jun and Cai (2010), Dabholkar et } \\
\text { al. (2000); Mechinda and } \\
\text { Patterson (2011), Winsted (2000) }\end{array}$ \\
\hline & $\begin{array}{l}\text { 12. The employee cared about } \\
\text { you }\end{array}$ & Winsted (2000) \\
\hline & $\begin{array}{l}\text { 13. The employee asked you how } \\
\text { you were }\end{array}$ & Winsted (2000) \\
\hline & $\begin{array}{l}\text { 14. The employee treated you } \\
\text { carefully }\end{array}$ & Winsted (2000) \\
\hline & 15. The employee was warm & Winsted (2000) \\
\hline & $\begin{array}{l}\text { 16. The employee was willing to } \\
\text { bend company policies to } \\
\text { help address your needs }\end{array}$ & Sirdeshmukh et al. (2002) \\
\hline
\end{tabular}




\begin{tabular}{|c|c|c|}
\hline & $\begin{array}{l}\text { 17. The employee did not } \\
\text { pressure you into buying }\end{array}$ & Dabholkar et al. (2000) \\
\hline \multirow[t]{10}{*}{ 3. Trust } & $\begin{array}{l}\text { 18. The employee's opinion was } \\
\text { honest and reliable }\end{array}$ & $\begin{array}{l}\text { Yim et al. (2008), Winsted (2000), } \\
\text { Sirdeshmukh et al. (2002) }\end{array}$ \\
\hline & $\begin{array}{l}\text { 19. The employee was a person } \\
\text { you could trust }\end{array}$ & Yim et al. (2008) \\
\hline & $\begin{array}{l}\text { 20. The employee was a person } \\
\text { you had a confidential } \\
\text { relationship with }\end{array}$ & Bügel (2010) \\
\hline & $\begin{array}{l}\text { 21. The employee's behavior } \\
\text { instilled confidence in you }\end{array}$ & $\begin{array}{l}\text { Jun and Cai (2010), Dabholkar et } \\
\text { al. (2000) }\end{array}$ \\
\hline & $\begin{array}{l}\text { 22. The employee made you feel } \\
\text { safe in your transaction with } \\
\text { the organization }\end{array}$ & Jun and Cai (2010) \\
\hline & 23. The employee was sincere & Winsted (2000) \\
\hline & $\begin{array}{l}\text { 24. The employee made you feel } \\
\text { comfortable }\end{array}$ & Winsted (2000) \\
\hline & $\begin{array}{l}\text { 25. The employee was natural } \\
\text { and genuine }\end{array}$ & Winsted (2000) \\
\hline & $\begin{array}{l}\text { 26. The employee promised to do } \\
\text { something by a certain time } \\
\text { and then did it at that time }\end{array}$ & Dabholkar et al. (2000) \\
\hline & $\begin{array}{l}\text { 27. The employee promised to do } \\
\text { something in a certain way } \\
\text { and then did it in that way }\end{array}$ & Dabholkar et al. (2000) \\
\hline \multirow[t]{7}{*}{$\begin{array}{l}\text { 4. Needs } \\
\text { understanding }\end{array}$} & $\begin{array}{l}\text { 28. The employee tried to meet } \\
\text { your needs }\end{array}$ & Yim et al. (2008) \\
\hline & $\begin{array}{l}\text { 29. The employee considered } \\
\text { what you had to say }\end{array}$ & $\begin{array}{l}\text { Mechinda and Patterson (2011), } \\
\text { Winsted (2000) }\end{array}$ \\
\hline & $\begin{array}{l}\text { 30. The employee was interested } \\
\text { in your needs }\end{array}$ & $\begin{array}{l}\text { Mechinda and Patterson (2011), } \\
\text { Winsted (2000) }\end{array}$ \\
\hline & $\begin{array}{l}\text { 31. The employee anticipated } \\
\text { your needs }\end{array}$ & $\begin{array}{l}\text { Mechinda and Patterson (2011), } \\
\text { Lloyd and Luk (2011), Winsted } \\
(2000)\end{array}$ \\
\hline & $\begin{array}{l}\text { 32. The employee asked for your } \\
\text { preferences }\end{array}$ & Lloyd and Luk (2011) \\
\hline & $\begin{array}{l}\text { 33. The employee understood } \\
\text { your needs }\end{array}$ & Lloyd and Luk (2011) \\
\hline & $\begin{array}{l}\text { 34. The employee treated you as } \\
\text { a valued customer }\end{array}$ & $\begin{array}{l}\text { Jun and Cai (2010), Sirdeshmukh } \\
\text { et al. (2002) }\end{array}$ \\
\hline 5. Courtesy & $\begin{array}{l}\text { 35. The employee was courteous } \\
\text { with you }\end{array}$ & $\begin{array}{l}\text { Yim et al. (2008), Mechinda and } \\
\text { Patterson (2011), Jun and Cai }\end{array}$ \\
\hline
\end{tabular}




\begin{tabular}{|c|c|c|}
\hline & & (2010), Dabholkar et al. (2000) \\
\hline & 36. The employee respected you & $\begin{array}{l}\text { Mechinda and Patterson (2011), } \\
\text { Winsted (2000), Sirdeshmukh et } \\
\text { al. (2002) }\end{array}$ \\
\hline & 37. The employee was helpful & $\begin{array}{l}\text { Mechinda and Patterson (2011), } \\
\text { Lloyd and Luk (2011), Winsted } \\
\text { (2000), Dabholkar et al. (2000) }\end{array}$ \\
\hline & 38. The employee was attentive & $\begin{array}{l}\text { Mechinda and Patterson (2011), } \\
\text { Winsted (2000) }\end{array}$ \\
\hline & $\begin{array}{l}\text { 39. The employee showed } \\
\text { patience with you }\end{array}$ & Lloyd and Luk (2011) \\
\hline & $\begin{array}{l}\text { 40. The employee addressed } \\
\text { complaints in a friendly } \\
\text { manner }\end{array}$ & Jun and Cai (2010) \\
\hline & 41. The employee was polite & $\begin{array}{l}\text { Lloyd and Luk (2011), Winsted } \\
(2000)\end{array}$ \\
\hline & $\begin{array}{l}\text { 42. The employee was not } \\
\text { annoyed with you }\end{array}$ & Winsted (2000) \\
\hline 6. Responsiveness & $\begin{array}{l}\text { 43. The employee was responsive } \\
\text { to your questions and } \\
\text { requests }\end{array}$ & Yim et al. (2008) \\
\hline & $\begin{array}{l}\text { 44. The employee took the time } \\
\text { to give you service }\end{array}$ & $\begin{array}{l}\text { Mechinda and Patterson (2011), } \\
\text { Winsted (2000), Dabholkar et al. } \\
(2000)\end{array}$ \\
\hline & $\begin{array}{l}\text { 45. The employee was readily } \\
\text { available when you needed } \\
\text { him }\end{array}$ & $\begin{array}{l}\text { Mechinda and Patterson (2011), } \\
\text { Winsted (2000) }\end{array}$ \\
\hline & $\begin{array}{l}\text { 46. The employee gave you } \\
\text { his/her full attention }\end{array}$ & Winsted (2000) \\
\hline & $\begin{array}{l}\text { 47. The employee was fully } \\
\text { engaged with you }\end{array}$ & Winsted (2000) \\
\hline 7. Capability & 48. The employee was intelligent & $\begin{array}{l}\text { Mechinda and Patterson (2011), } \\
\text { Winsted (2000) }\end{array}$ \\
\hline & 49. The employee was capable & $\begin{array}{l}\text { Mechinda and Patterson (2011), } \\
\text { Dabholkar et al. (2000) }\end{array}$ \\
\hline & $\begin{array}{l}\text { 50. The employee behaved in a } \\
\text { professional manner }\end{array}$ & Mechinda and Patterson (2011) \\
\hline & $\begin{array}{l}\text { 51. The employee showed } \\
\text { passion for their job }\end{array}$ & Lloyd and Luk (2011) \\
\hline & $\begin{array}{l}\text { 52. The employee was } \\
\text { knowledgeable }\end{array}$ & $\begin{array}{l}\text { Lloyd and Luk (2011), Winsted } \\
\text { (2000), Dabholkar et al. (2000) }\end{array}$ \\
\hline & 53. The employee knew what & Sirdeshmukh et al. (2002) \\
\hline
\end{tabular}




\begin{tabular}{|c|c|c|}
\hline & he/she was doing & \\
\hline \multirow[t]{9}{*}{ 8. Service manner } & $\begin{array}{l}\text { 54. The employee was happy and } \\
\text { cheerful }\end{array}$ & Mechinda and Patterson (2011) \\
\hline & 55. The employee smiled a lot & $\begin{array}{l}\text { Mechinda and Patterson (2011), } \\
\text { Lloyd and Luk (2011), Winsted } \\
(2000)\end{array}$ \\
\hline & $\begin{array}{l}\text { 56. The employee had a sincere } \\
\text { facial expression }\end{array}$ & $\begin{array}{l}\text { Mechinda and Patterson (2011), } \\
\text { Winsted (2000) }\end{array}$ \\
\hline & $\begin{array}{l}\text { 57. The employee was } \\
\text { enthusiastic }\end{array}$ & $\begin{array}{l}\text { Mechinda and Patterson (2011), } \\
\text { Winsted (2000) }\end{array}$ \\
\hline & $\begin{array}{l}\text { 58. The employee talked with } \\
\text { you }\end{array}$ & $\begin{array}{l}\text { Mechinda and Patterson (2011), } \\
\text { Winsted (2000) }\end{array}$ \\
\hline & $\begin{array}{l}\text { 59. The employee was relaxing to } \\
\text { interact with }\end{array}$ & Lloyd and Luk (2011) \\
\hline & 60. The employee was cheerful & $\begin{array}{l}\text { Lloyd and Luk (2011), Winsted } \\
(2000)\end{array}$ \\
\hline & $\begin{array}{l}\text { 61. The employee did not act } \\
\text { arrogantly }\end{array}$ & Winsted (2000) \\
\hline & $\begin{array}{l}\text { 62. The employee had a good } \\
\text { attitude }\end{array}$ & Winsted (2000) \\
\hline
\end{tabular}


APPENDIX 2: CUSTOMER LOYALTY ITEMS

This appendix gives an overview of items which measure customer loyalty.

\begin{tabular}{|l|l|}
\hline Customer loyalty item & Sources \\
\hline $\begin{array}{l}\text { You consider this company your first choice when choosing the service } \\
\text { (First choice) }\end{array}$ & $\begin{array}{l}\text { Yim et al. } \\
\text { (2008) }\end{array}$ \\
\hline This is a company you prefer over others (Preference) & $\begin{array}{l}\text { Yim et al. } \\
(2008)\end{array}$ \\
\hline $\begin{array}{l}\text { You would continue to visit this company even if it increases prices. } \\
\text { (Visits) }\end{array}$ & $\begin{array}{l}\text { Yim et al. } \\
\text { (2008) }\end{array}$ \\
\hline $\begin{array}{l}\text { To what extend do you intend to remain a customer with this company? } \\
\text { (Loyalty) }\end{array}$ & Bügel (2010) \\
\hline $\begin{array}{l}\text { To what extent do you feel committed to the company, even if you had } \\
\text { less than positive experiences with it? (Commitment) }\end{array}$ & Bügel (2010) \\
\hline How often do you consider switching to another company? (Switch) & Bügel (2010) \\
\hline $\begin{array}{l}\text { How likely are you to recommend this company to friends, neighbors } \\
\text { and relatives? (Recommendation) }\end{array}$ & $\begin{array}{l}\text { Sirdeshmukh et } \\
\text { al. (2002) }\end{array}$ \\
\hline
\end{tabular}




\section{APPENDIX 3: THE EXCELLENT SERVICES QUESTIONNAIRE}

This research looks at the ways companies can provide excellent service to their customers. For this, we would like to ask you about your experiences with a company which provided you with outstanding service. Please think back to a time when you encountered first-rate service which surpassed your expectations, and rate on a scale of 1 (not important at all) to 10 (very important) the importance of the following behaviors of the company's staff for your outstanding experience.

1. The staff provided you with prompt service

2. The staff provided you with accurate service

3. The staff provided you with reliable service

4. The staff solved your problem quickly

5. The staff solved your problem completely

6. The staff provided you with complete service

7. The staff went out of their way to solve your problems

8. The staff performed the service right the first time

9. The staff's service had much added value for you

10. The staff was very understanding of your situation

11. The staff gave you personal attention

12. The staff cared about you

13. The staff asked you how you were

14. The staff treated you carefully

15. The staff was warm toward you

16. The staff were willing to bend company policies to help address your needs

17. The staff did not pressure you into buying

18. The staff's opinion was honest and reliable

19. The staff was a person you could trust

20. The staff was a person you had a confidential relationship with

21 . The staff's behavior instilled confidence in you

22. The staff made you feel safe in your transaction with the organization

23. The staff was sincere toward you

24. The staff made you feel comfortable 
25. The staff was natural and genuine

26. The staff promised to do something by a certain time and then did it at that time

27. The staff promised to do something in a certain way and then did it in that way

28. The staff tried to meet your needs

29. The staff considered what you had to say

30. The staff was interested in your needs

31. The staff anticipated your needs

32. The staff asked for your preferences

33. The staff understood your needs

34 . The staff treated you as a valued customer

35. The staff was courteous with you

36. The staff respected you

37. The staff was helpful toward you

38. The staff was attentive toward you

39. The staff showed patience with you

40. The staff addressed your complaints in a friendly manner

41. The staff was polite toward you

42. The staff was not annoyed with you

43. The staff was responsive to your questions and requests

44. The staff took the time to give you service

45. The staff was readily available when you needed him

46. The staff gave you his full attention

47. The staff was fully engaged with you

48. The staff was intelligent

49. The staff was capable

50. The staff behaved in a professional manner

51. The staff showed passion for their job

52. The staff was knowledgeable

53. The staff knew what they were doing

54. The staff was happy and cheerful

55. The staff smiled a lot

56. The staff had a sincere facial expression

57. The staff was enthusiastic 
58. The staff talked with you

59. The staff was relaxing to interact with

60. The staff was cheerful

61. The staff did not act arrogantly

62. The staff had a good attitude

Based on your experience with the company, how likely are you $(1=$ not at all; $10=$ most definitive) to:

63. consider this company your first choice when choosing the service?

64. Prefer this company over others when doing future business?

65. Visit this company even if it increases prices?

66. To remain customer with this company?

67. To consider switching to another company?

68. To stay committed to the company, even if you will have less than positive experiences with it in future?

69. To recommend this company to friends, neighbors and relatives? 